\title{
ARTICLE \\ Inducement of apoptosis by cucurbitacin E, a tetracyclic triterpenes, through death receptor 5 in human cervical cancer cell lines
}

\author{
Ya-Min Cheng ${ }^{1}$, Ching-Ju Shen ${ }^{2}$, Chi-Chang Chang ${ }^{3,4}$, Cheng-Yang Chou ${ }^{1}$, Ching-Chou Tsai ${ }^{5,6}$ and Yi-Chiang Hsu ${ }^{4,7}$
}

Cervical cancer is the most common malignancy in women, for which conization or hysterectomy are the main therapy. Curcubitacin E ( $\mathrm{Cu} \mathrm{E})$ is a natural compound-based drug which from the Guadi (climbing stem of Cucumic melo L). Previously shown to be an anti-tumor as well as a potent chemopreventive agent against several types of tumors. The present study, investigated anti-proliferation and apoptosis induced by $\mathrm{Cu} \mathrm{E}$ in cervical cancer cell lines (HeLa and Ca Ski). The results indicate that the cytotoxicity is associated with accumulation in apoptosis but not necrosis. Cu E produced apoptosis as well as the up-regulation the expression of death receptor 5 (DR5). In addition, the DR5 gene activation in apoptosis, both effects increased proportionally with the dose of $\mathrm{Cu} \mathrm{E}$; however, mitosis delay was also dependant on the amount of $\mathrm{Cu} \mathrm{E}$ treatment in the cancer cells. These results indicate that Cu E may delay cancer cell growth by apoptosis via upregulation of DR5 gene expression.

Cell Death Discovery (2017) 3, 17014; doi:10.1038/cddiscovery.2017.14; published online 24 April 2017

\section{INTRODUCTION}

Cervical cancer is the sixth most common cancerous malignancy in females in Taiwan, and a leading cause of death among gynecological malignancies. ${ }^{1}$ The majority of women diagnosed with this cancer exhibit an advanced, widely disseminated malignancy and poor survival rate. ${ }^{2}$ Infections with human papillomavirus (HPV), predisposition, as well as various factors are believed to have important roles in the development of carcinogenesis. ${ }^{3}$ Overwhelming evidence has demonstrated that oncogenic types of HPV play an important role in the development of precursors of cervical cancer. ${ }^{4}$ However, only a small fraction of females infected with HPV develop the disease, indicating the contribution of other factors to the progression of lesions in invasive cervical cancer. ${ }^{5}$

Many studies indicate a positive correlation between the consumption of natural components of certain plants and the decreased incidence of some tumors including prostate, cervical, ovarian, lung and gastrointestinal tract. ${ }^{6-7}$ Cucurbitacins are a group of tetracyclic triterpenes with medicinal properties derived from the climbing stem (Gua di) of Cucumic melo L. ${ }^{8}$ Gua di has been used extensively in traditional folk medicines throughout Asia, providing selective biological activities. ${ }^{9}$ Interest in this herb has grown in recent years due to its putative beneficial pharmacological effects as an anti-inflammatory ${ }^{10}$ and anti-cancer agent. ${ }^{11}$ There have also been indications that cucurbitacins may help to prevent and treat oxidative damage as well as suppress specific inflammatory factors. ${ }^{12}$
Cucurbitacin E (Cu E) is an active compound, which was previously shown to be a strong anti-feedant with the ability to disrupt cell actin and adhesion. ${ }^{13}$ Recent our studies have reported that $\mathrm{Cu} \mathrm{E}$ has an inhibitory effect on the proliferation of cancer cells. ${ }^{14}$ However, it remains unclear whether $\mathrm{Cu} E$ inhibits the growth of cervical cancer cells. Furthermore, the mechanism underlying the anti-cancer effects of $\mathrm{Cu} \mathrm{E}$ has yet to be identified.

This present study was initiated to investigate whether $\mathrm{Cu} \mathrm{E}$ contributes to the anti-proliferation and apoptosis induction of cervical cancer cell lines (HeLa and Ca Ski). It is expected that these experiments will provide scientific basis and technological support for further development of cervical cancer therapy.

\section{RESULTS}

Cu E can mediate the survival of cervical cancer cells, and thus inhibits their growth

To explore this anti-tumor activity, an in vitro study was conducted in which HeLa and Ca Ski cells were subjected to increasing dosages of $\mathrm{Cu} \mathrm{E}(0,1.25,2.5$ and $5 \mu \mathrm{M})$ for 1 to 3 days. The proliferation of $\mathrm{Cu}$ E-treated cancer cells were then measured using the MTT method (Figure 1a). The results indicate that the survival and proliferation of Hela and Ca Ski cells was decreased by Cu E treatment in a dose- and time-dependent manner. (HeLa: $y=-13.224 x+108.09, R^{2}=0.9077$ (24h), $y=-16.585 x+107.48, R^{2}=0.8304(48 \mathrm{~h}), y=-20.23 x+118.58$, $R^{2}=0.9672(72 \mathrm{~h}) ;$ Ca Ski: $y=-12.309 x+109.15, R^{2}=0.9432(24 \mathrm{~h})$, $y=-17.794 x+108.13, \quad R^{2}=0.8341 \quad(48 h), \quad y=-18.951 x+107.19$, $\left.R^{2}=0.7949(72 \mathrm{~h})\right)$.

\footnotetext{
${ }^{1}$ Department of Obstetrics and Gynecology, National Cheng Kung University Hospital, College of Medicine, National Cheng Kung University, Tainan, Taiwan; ${ }^{2}$ Department of Gynecology and Obstetrics, Kaohsiung Medical University Hospital, Kaohsiung Medical University, Kaohsiung, Taiwan; ${ }^{3}$ Department of Obstetrics \& Gynecology, E-Da Hospital, E-Da Hospital/I-Shou University, Kaohsiung, Taiwan; ${ }^{4}$ Graduate Institute of Medical Science, College of Health Sciences, Chang Jung Christian University, Tainan, Taiwan; ${ }^{5}$ Division of Gynecologic Oncology, Department of Obstetrics and Gynecology, Chang Gung Memorial Hospital and Chang Gung University College of Medicine, Kaohsiung, Taiwan; ${ }^{6}$ Department of Obstetrics and Gynecology, Chang Gung Memorial Hospital, Chang Gung University College of Medicine Kaohsiung, Kaohsiung, Taiwan and ${ }^{7}$ Bachelor Degree Program of Medical Sciences Industry, College of Health Sciences, Chang Jung Christian University, Tainan, Taiwan.

Correspondence: Y-M Cheng (chengym@mail.ncku.edu.tw) or Y-C Hsu (jenway@mail.cjcu.edu.tw)

Received 1 December 2016; revised 11 January 2017; accepted 22 January 2017; Edited by A Rufini
} 


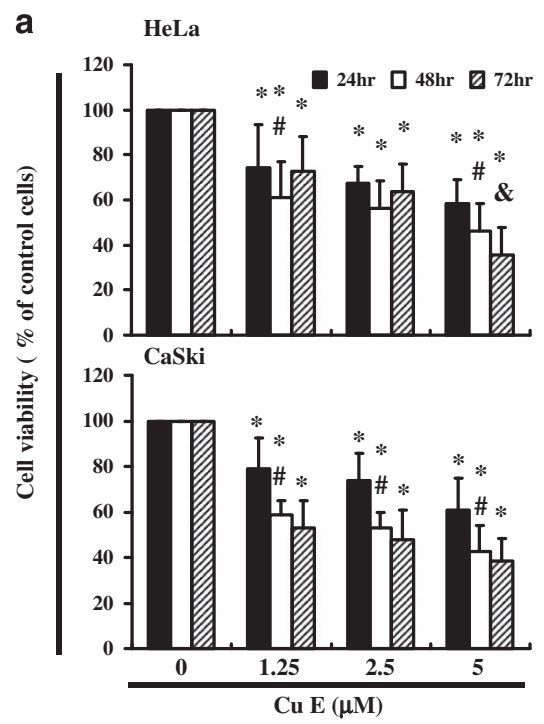

C HeLa
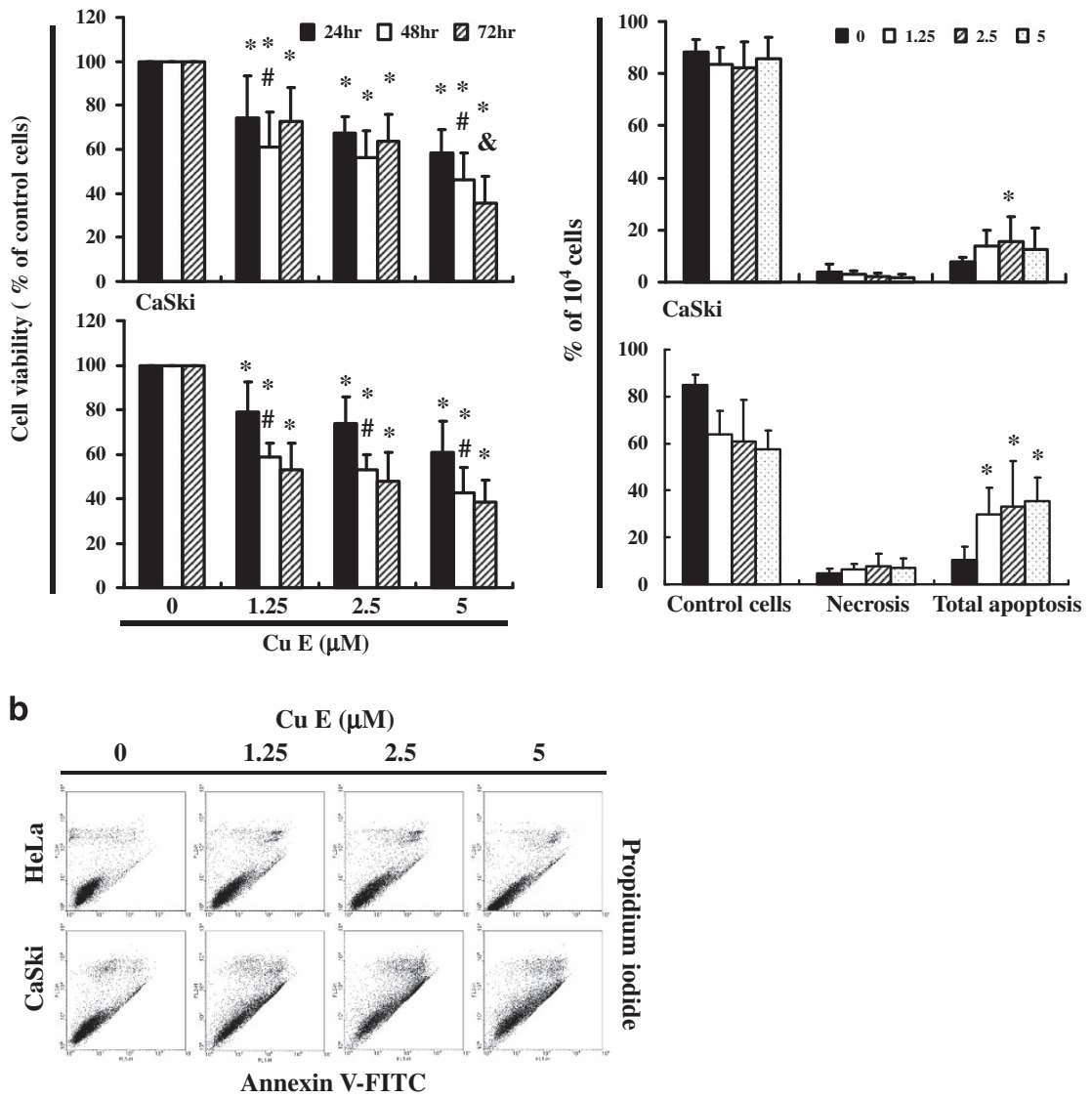

Figure 1. Cu E mediates the survival of cervical cancer cells (HeLa and Ca Ski), thereby inhibiting proliferation. (a) An in vitro study was initiated by treating each of the cell lines with increasing doses of $\mathrm{Cu} E(0,1.25,2.5$ and $5 \mu \mathrm{M})$ for 1-3 days. The survival of $\mathrm{Cu} E$-treated cancer cell lines was then measured by MTT method. (b) Total apoptosis and necrosis in cervical cancer cell lines after $4 \mathrm{~h}$ of incubation with Cu E. (c) Results were expressed as a percentage of normal group (control cells), necrosis and the total number of apoptotic cells (early and late apoptosis). Results were expressed as a percentage of control, which was considered $100 \%$. All data were reported as the mean ( \pm S.E.M.) of at least three separate experiments. Statistical analysis was performed using a $t$-test, with significant differences determined at the level of $* P<0.05$ versus the control group, ${ }^{\#} P<0.05$ versus the $24 \mathrm{~h}$ group, ${ }^{\circledR} P<0.05$ versus the $48 \mathrm{~h}$ group.

Cu E-induced apoptosis of cervical cancer cell lines

To identify the role played by $\mathrm{Cu} \mathrm{E}$ in the apoptosis/necrosis of cervical cancer cell lines, we employed Annexin V-FITC and propidium iodide staining to reveal the formation of apoptotic cells following $4 \mathrm{~h}$ of exposure to $\mathrm{CU}$ E. The percentage of apoptotic cells was assessed by flow cytometric analysis (Figure 1b). A dot-plot of Annexin V-FITC fluorescence versus PI fluorescence indicates a significant increase in the percentage of apoptotic cells treated with $\mathrm{Cu}$ E, compared with untreated cells. Significant increase was observed in the percentage of cells undergoing apoptosis (Figure 1c).

$\mathrm{Cu}$ E-induced accumulation of Sub $\mathrm{G}_{1}$ phase in $\mathrm{Cu}$ E-treated cells The cell cycle distribution of Cu E-treated cells was analyzed by flow cytometry. Cells were exposed to Cu E for $24 \mathrm{~h}$ before processing and analysis. As shown in Figure $2 \mathrm{a}$, exposure to $\mathrm{Cu} \mathrm{E}$ resulted in an increase in the number of $G_{2} / M$ phase and sub $G_{1}$, cells, which may imply that the cervical cancer cells underwent cell cycle arrest and apoptosis. The results indicate that treatment with $\mathrm{Cu} E$ increased the cell populations in sub G1 (HeLa: $y=2.5136 x+3.1373, \quad R^{2}=0.8259 ; \quad$ Ca Ski: $y=0.7428 x+5.4593$, $R^{2}=0.1811$ ), while simultaneously reducing the number of cells in the $G_{1}$ phases in HeLa cells ( ${ }^{*} P<0.05$ versus $\mathrm{Cu} E 0 \mu \mathrm{M}$ ) $\left(y=-3.6922 x+51.15, R^{2}=0.244\right)$ (Figure 2b).
Assessment of changes in mitochondrial membrane potential The loss of mitochondrial membrane potential is a hallmark for apoptosis. It is an early event coinciding with caspase activation. In non-apoptotic cells, JC-1 exists as a monomer in the cytosol (green) and accumulates as aggregates in the mitochondria, which appear red. In apoptotic and necrotic cells, JC-1 exists in monomeric form and stains the cytosol green. Figure $2 \mathrm{c}$ shows typical FL-1/FL-2 dot plots for JC-1 staining HeLa and Ca Ski cells with apoptosis. Cu E-free cancer cells are without apoptosis, which have red fluorescing J-aggregates. The green fluorescing monomers shown in the lower part indicate apoptotic cells. Figure $2 \mathrm{~d}$ shows the percentages of apoptotic cells analyzed by flow cytometer in different $\mathrm{Cu}$ E-treated groups. Taken together, the observations imply that $\mathrm{Cu} E$ has significantly reduced the mitochondrial membrane potential of HeLa and $\mathrm{Ca}$ Ski cells. Moreover, we detected caspase 3 activation at $\mathrm{Cu}$ E concentrations of 1.25 to $5 \mu \mathrm{M}$ in HeLa $(y=3.3754 x-1.0423$, $\left.R^{2}=0.8835\right)$ and Ca Ski cells $\left(y=1.9717 x+3.0832, R^{2}=0.8243\right)$ (Figures $2 \mathrm{e}$ and $\mathrm{f}$ ), indicating induction of apoptosis in treated cells. There are also significant change was observed in the pro-caspase 3, -8 and -9 in Cu E-treated Ca Ski cells (Figures 3a and b).

In summary, the results summarized in Figures 1-3 suggest that $\mathrm{Cu} \mathrm{E}$ affects the survival of cervical cancer cell lines inducing mitochondrial depolarization and apoptosis. 
a

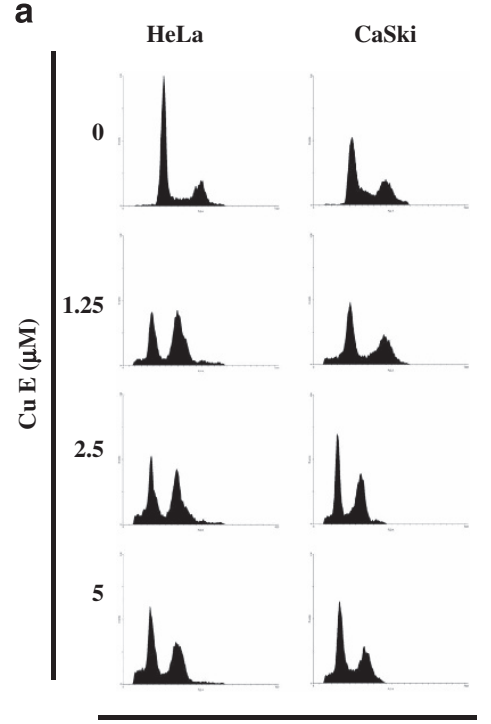

DNA Content

C

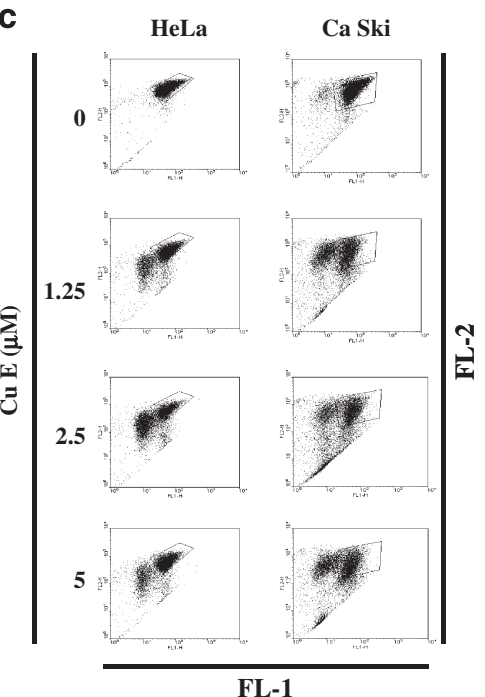

f

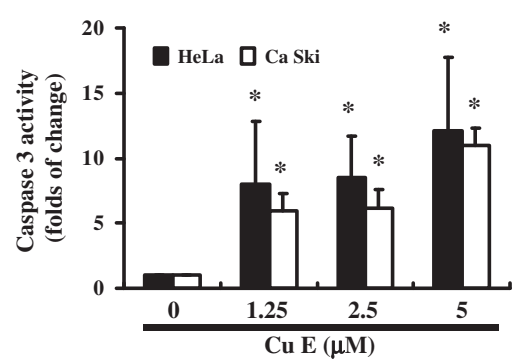

b

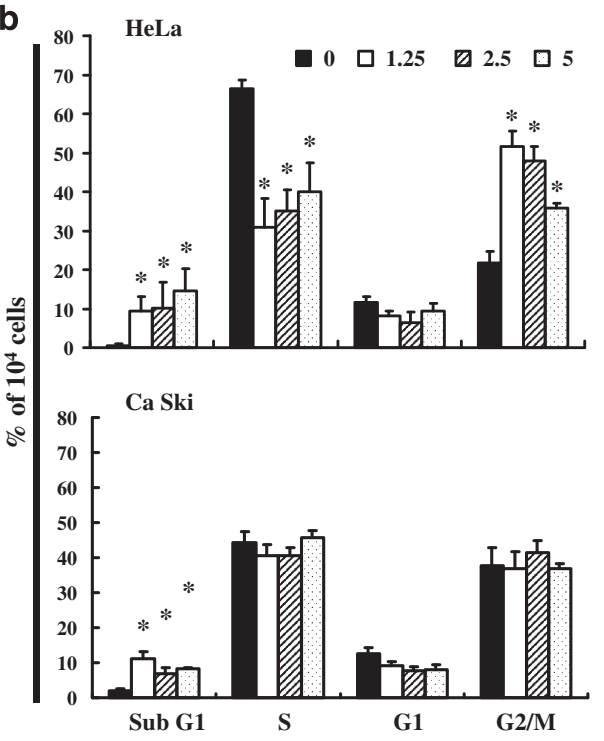

d
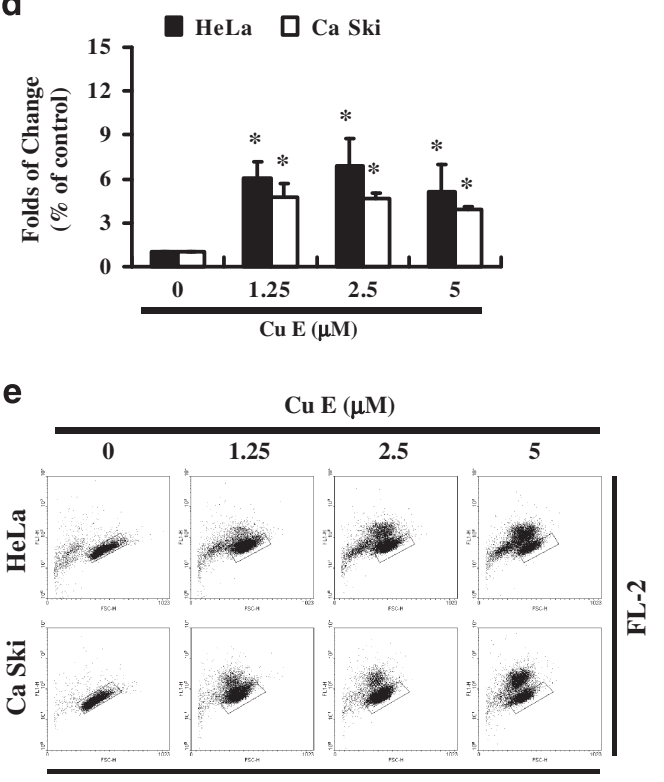

FL-1

Figure 2. Influence of $\mathrm{Cu} \mathrm{E}$ on cell cycle progression/distribution in cervical cancer cells: (a) Cell cycle analysis of HeLa and Ca Ski cells after being cultured with $\mathrm{Cu} \mathrm{E}$ for $24 \mathrm{~h}$. (b) Cu E induced an increase in sub $\mathrm{G}_{1}$ phase cells (\%). (c) Cu E mediated mitochondrial membrane potential $(\Delta \Psi \mathrm{m})$-dependent anti-proliferation in HeLa and Ca Ski cells. The levels of $\Delta \Psi \mathrm{m}$ which was determined by JC- 1 staining and flow cytometry and (d) Quantification through flow cytometry. (e) The cells were treated with Cu E for $24 \mathrm{~h}$. Following treatment, the cells were harvested and labeled using FITC rabbit anti-active caspase 3. Activation was quantified by flow cytometry. (f) Quantification by flow cytometry. Symbol $(*)$ in each group of bars indicates that the difference resulting from treatment with Cu E $0 \mu \mathrm{M}$ is statistically significant at $P<0.05$.

Apoptosis induction in Cu E-treated cells via DR5 upregulation Figures $4 a-c$ illustrate DR5 gene expression in cervical cancer cells (Figure $4 a$ ) and immunoblotting results of cellular proteins from HeLa and Ca Ski cell lines treated with Cu E (Figure 4d). Gene expression and western blot analysis revealed an increase in DR5 following incubation with Cu E (Figures $4 d$ and e).
These data suggest that DR5 level regulated the tumorigenicity of cervical cancer cells via $\mathrm{Cu}$ E. These findings indicate that common molecular pathways are involved in inducing apoptosis. Findings from qPCR analysis were further validated by $a$ microarray analysis (data not shown), which indicated substantial TNF up-regulation (relative expression ratio 3.08 ) as well as 

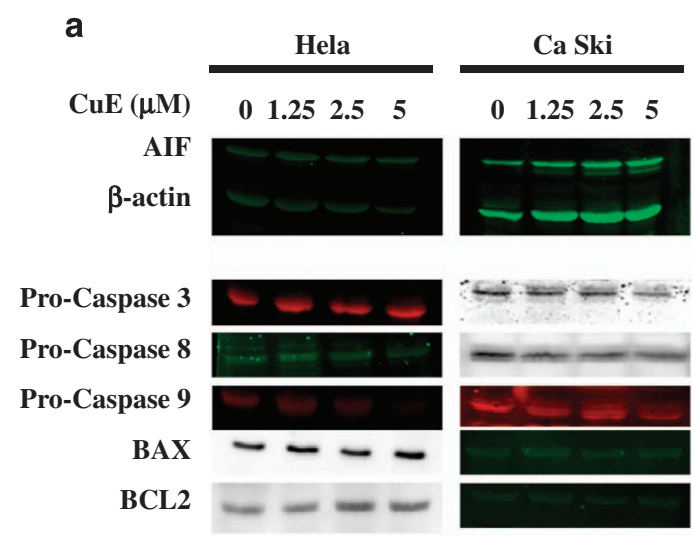

b

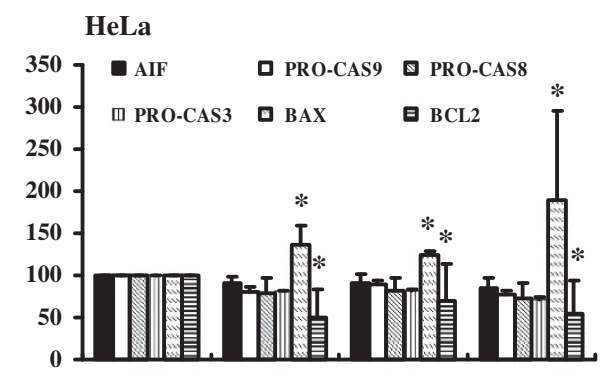

Ca Ski

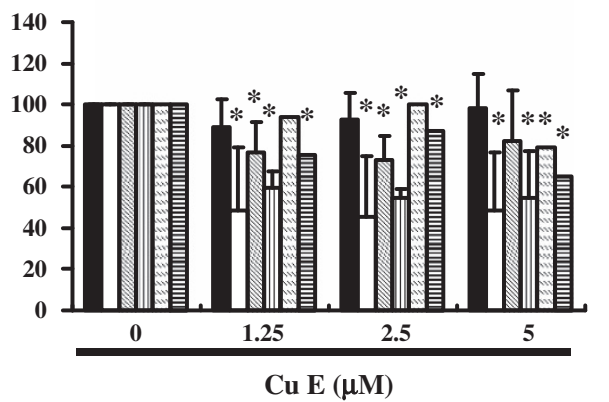

Figure 3. The genes down- or up-regulated in HeLa and Ca Ski cells following exposure to $\mathrm{Cu}$ E. The AIF, BAX, BCL-2 and caspase 3, -8 , -9 gene expression profile was studied in cervical cancer cells exposed to the vehicle (DMSO) or to the Cu E. (a) Western blotting (b) qPCR. Symbol $\left(^{*}\right)$ in each group of bars indicates that the difference resulting from treatment with $\mathrm{Cu} \mathrm{E} 0 \mu \mathrm{M}$ is statistically significant at $P<0.05$.

notable upregulation of DR5 (relative expression ratio 7.46) in cervical cancer cells following exposure to $\mathrm{Cu}$ E.

\section{DISCUSSION}

$\mathrm{Cu} \mathrm{E}$ or $a$-elaterin is a natural compound previously shown to be an anti-feedant drig as well as a potent chemotherapy agent against several types of tumor. ${ }^{15}$ The most common cell death mode on $\mathrm{CU} \mathrm{E}$ treatment seems to be apoptosis, cell cycle regulation and many studies have attempted to elucidate the mechanism underlying the anti-cancer activity of this compound. ${ }^{16}$

Tumor necrosis factor (TNF)-related apoptosis-inducing ligand (TRAIL) is a secreted protein belonging to tumor necrosis factor superfamily of cell death-inducing ligands. ${ }^{17}$ TRAIL drives the onset of extrinsic apoptosis pathways after binding to its receptors Death receptor 4 (DR4, Trail-R1, Apo2 and Tnfrsf10A) and Death receptor 5 (DR5, Trail-R2, Trick2 and Tnfrsf10B). ${ }^{18}$ DR5 is a cell surface receptor of the TNF-receptor superfamily that binds TRAIL and mediates apoptosis. ${ }^{19}$ it is a promising target for cancer therapy due to its ability to selectively induce apoptosis in cancer cells. $^{20,21}$

In this study, Cu E demonstrated anti-proliferation activity as well as the ability to induce apoptosis. We found that treating cervical cancer cells with $\mathrm{Cu} E$ resulted not only the repressed the progression of cell cycle in $\mathrm{G}_{2} / \mathrm{M}$ (Cu E 1.25 and $2.5 \mu \mathrm{M}$; Figures $2 \mathrm{a}$ and $b$ ) but also induced the apoptosis by upregulation of DR5.

The results collected in this series of studies provide experimental evidence supporting the contention that $\mathrm{Cu} \mathrm{E}$ may irreversibly arrest the growth of cervical cancer cells. The results of mechanistic analysis led to the conclusion that both the inhibition of proliferation and the induction of apoptosis are highly dependent upon $\mathrm{Cu} \mathrm{E}$ accumulated in the cancer cells.

In conclusion, this study demonstrates for the first time that $\mathrm{Cu}$ $E$ is an effective inhibitor of cervical cancer. The role of $\mathrm{Cu} E$ in the inhibition of tumor growth was highlighted by apoptosis induction through the upregulation of DR5 expression. These findings suggest the applicability of $\mathrm{Cu} E$ as an anti-tumor agent for cervical cancer chemoprevention.

\section{MATERIALS AND METHODS}

\section{Materials}

Cucurbitacin E, DMSO (dimethyl sulfoxide) and MTT [3-(4,5-dimethylthiazol-2-yl)- 2,5-diphenyltetrazolium bromide] were obtained from SigmaAldrich (St Louis, MO, USA). Cell culture medium (MEM and RPMI 1640), phosphate-buffered saline (PBS), anti-biotics, sodium pyruvate, L-glutamine, trypsin and fetal bovine serum (FBS) were purchased from Gibco, BRL (Grand Island, NY). Polyvinylidene fluoride membrane (PVDF) (Millipore), and molecular weight marker were purchased from Bio Rad (USA). All other reagents and compounds were analytical grades.

\section{Cells}

The HeLa and Ca Sk cells were purchased from ATCC. The cells were maintained on culture dishes, in $90 \%$ (v/v) MEM Eagle or RPMI1640 with $2 \mathrm{mM}$ L-glutamine and Earle's BSS adjusted to contain $1.5 \mathrm{~g} / \mathrm{l}$ sodium bicarbonate, $0.1 \mathrm{mM}$ non-essential amino acid (NEAA) and $1 \mathrm{mM}$ sodium pyruvate with $10 \%(\mathrm{v} / \mathrm{v}) \mathrm{FBS}$. The cells were cultured in an atmosphere containing $5 \% \mathrm{CO}_{2}$ at $37^{\circ} \mathrm{C}$ incubator.

\section{Cell proliferation assay}

The cancer cells were seeded into 96-wells culture plate at 5000 cells/well. The cells were treated with $0,1.25,2.5$ and $5 \mu \mathrm{M} \mathrm{Cu} \mathrm{E}$, the $\mathrm{Cu}$ E will complex with culture medium. Then the cell will incubate in 37 degree $\mathrm{C}$ for 24,48 and $72 \mathrm{~h}$ in the $\mathrm{CO} 2$ incubator. After incubate 24,48 and $72 \mathrm{~h}$. The cell treatments MTT dye $(1 \mathrm{mg} / \mathrm{ml})$ at least $4 \mathrm{~h}$ on each well. The reaction was stopped by the addition of DMSO, and optical density was measured at $\mathrm{OD}_{540}$ on a multi-well plate reader. Background absorbance of the medium in the absence of cells was subtracted. All samples were assayed in triplicate, and the mean for each experiment was calculated. Results were expressed as a percentage of control, which was considered as $100 \%$. Each assay was carried out in triplicate and the results were expressed as the mean ( \pm S.E.M.).

\section{Measurement of apoptosis/necrosis}

Cervical cancer cell lines were first seeded in 6-well plates (Orange Scientific, E.U.). Following treatment with $\mathrm{CU} E$ for 4 hours, the cells were harvested. The cells were re-centrifuged (the supernatant discarded) and resuspended/incubated in $1 \mathrm{X}$ annexin-binding buffer. Five microliter of annexin V-FITC (BD Pharmingen, Franklin Lakes, NJ, USA) and $1 \mu \mathrm{l}$ of $100 \mu \mathrm{g} / \mathrm{ml} \mathrm{PI}$ working solution for $15 \mathrm{~min}$. Following the incubation period, the stained cells were analyzed using flow cytometry (FACSCalibur, BD, San Jose, CA, USA). Data was analyzed using WinMDI 2.9 free software (BD).

\section{Caspase 3 activity assay}

The caspase activity was assessed by the FITC rabbit anti-active caspase 3 (BD Pharmingen). The cells were treated with Cu E for $24 \mathrm{~h}$. Caspase 3 activition level was then measured by the flow cytometry (FACSCalibur). Data was analyzed using WinMDI 2.9 free software (BD) 
a

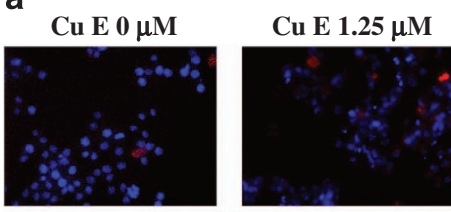

b

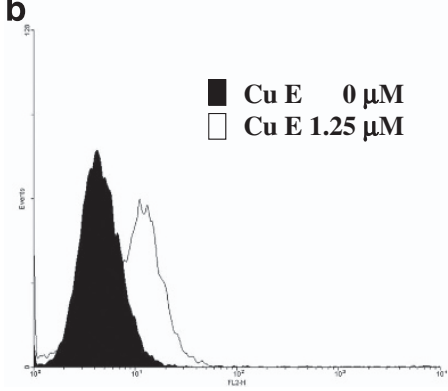

c

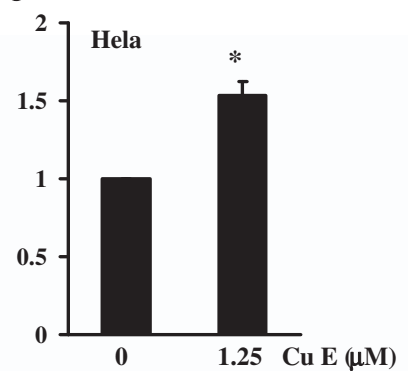

e

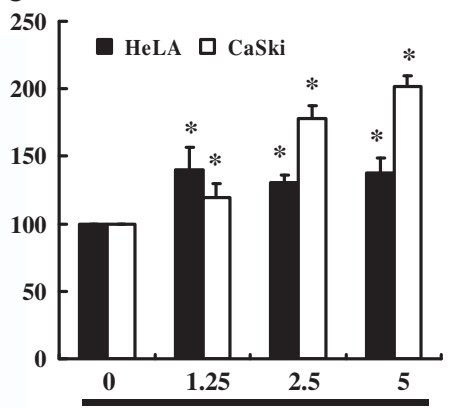

$\mathrm{Cu} \mathbf{E}(\mu \mathrm{M})$

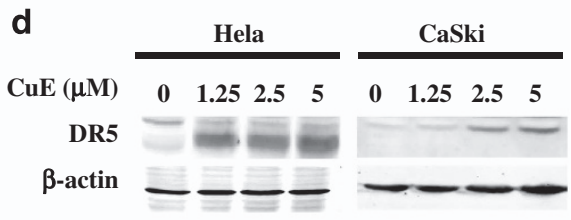

Figure 4. Influence of Cu E on DR5 expression in untreated and treated cancer cells. (a) Cells were dually stained using DAPI to analyze DNA content (blue) and DR5 protein (red) expression (b). (c) Quantification of DR5 expression was performed by flow cytometry following treatment with $\mathrm{Cu}$ E for $24 \mathrm{~h}$. (d) Cu E enhanced the level of DR5 in HeLa and Ca Ski cells. (e) DR5 expression was subsequently detected using Western blot analysis: Representative blots from three independent experiments. Quantification of band intensities. Symbol $(*)$ in each group of bars indicates that the difference resulting from treatment with $\mathrm{Cu} \mathrm{E} 0 \mu \mathrm{M}$ is statistically significant at $P<0.05$. Scale bar: $10 \mu \mathrm{m}$.

\section{Mitochondrial membrane potential}

The cell lines were first seeded in 6-well plates (Orange Scientific). Following treatment with $\mathrm{Cu}$ E for four hours, JC-1 $(25 \mu \mathrm{M})$ was added to the culture medium $\left(500 \mu \mathrm{l} /\right.$ well) and incubated $\left(37^{\circ} \mathrm{C}, 20 \mathrm{~min}\right)$ for mitochondrial staining. After washing twice with warm PBS, the cells were fixed using $2 \%$ paraformaldehyde. For JC-1, quantification by flow cytometry (BD FACScalibur) and mitochondria containing red JC-1 aggregates in healthy cells were detectable in the FL-2 channel, and green JC-1 monomers in apoptotic cells were detectable in the FL-1 channel.

\section{Cell cycle analysis}

For cell cycle analysis we used the fluorescent nucleic acid dye propidium iodide (PI) to identify the proportion of cells in each of the three interphase stages of the cell cycle. The cells were treated with $\mathrm{Cu} E$ for $24 \mathrm{~h}$, and then harvested and fixed in $1 \mathrm{ml}$ cold $75 \%$ ethanol for over night at $-20^{\circ} \mathrm{C}$. DNA was stained in $\mathrm{PI} / \mathrm{RN}$ aseA solution and the DNA content was detected using flow cytometry. Data was analyzed using WinMDI 2.9 free software.

\section{DR5 expression}

Confocal microscopy was performed as described previously. ${ }^{22}$ Briefly, The cells $\left(2 \times 10^{6}\right.$ cells) were fixed on coverslips. After treatment, they were incubated with mouse anti-DR5-phycoerythrin antibody (sc-166624 PE) (Santa Cruz BioTechnology, Dallas, TX, USA) for $30 \mathrm{~min}$, and then washed with PBS. The cells were mounted onto microscope slides using mounting medium containing DAPI. The cells were first seeded in 6-well plates (Orange Scientific). Following treatment and anti-DR5-PE antibody incubated $\left(37^{\circ} \mathrm{C}, 20 \mathrm{~min}\right)$ for protein staining. After washing twice with PBS, the cells were fixed using $2 \%$ paraformaldehyde. For DR5, quantification by flow cytometry (BD FACScalibur).

\section{Western blot assay}

A total of $50-100 \mu \mathrm{g}$ of proteins were separated by $10-12 \%$ SDS-PAGE, and transferred to PVDF membranes (Millipore, USA). The membranes were blocked with blocking buffer (Odyddey, USA) overnight, and incubated with anti- $\beta$-actin (Sigma-Aldrich), anti-caspase 3 (sc-7148), anti-caspase 8 (sc-6134), anti-caspase 9 (sc-7885), anti-AIF (sc-9417) and DR5 (sc-7192) antibodies for $1.5-2 \mathrm{~h}$. The blots were washed and incubated with a second antibody (IRDye Li-COR, USA) or conjugated with horseradish peroxidase (HRP) at a 1/20,000 dilution for $30 \mathrm{~min}$. The antigen was then visualized using a near infrared imaging system (Odyssey LI-COR, Lincoln, $\mathrm{NE}$, USA) or chemiluminescence detection kit (ECL; Amersham Corp., Arlington Heights, IL, USA). The data was analyzed using Odyssey 2.1 software.

\section{RT-PCR}

A reverse transcriptase system (Promega, Southampon, UK) was used to synthesize cDNA from $1 \mu \mathrm{g}$ of total RNA. Between 2 and $4 \mu \mathrm{l}$ of CDNA were used for PCR analysis. PCR $(50 \mu \mathrm{l})$ reactions were performed using $100 \mathrm{ng}$ of each primer and 1 unit of Dynazyme II (Flowgen, Lichfield, UK). Thermal cycling was conducted for 35 cycles at the following temperature/ durations: $98{ }^{\circ} \mathrm{C}$ for $10 \mathrm{~s}, 66^{\circ} \mathrm{C}$ for $30 \mathrm{~s}$, and $72{ }^{\circ} \mathrm{C}$ for 1 min using a Progene thermal cycler (Cambridge, UK). A final extension of $72{ }^{\circ} \mathrm{C}$ was performed for $10 \mathrm{~min}$ at the end of 35 cycles. The primers used for amplification of the target genes were checked against all other gene sequences for specificity. PCR reactions were analyzed on $1.5 \%$ agarose/TAE minigels and stained using $0.5 \mu \mathrm{g} / \mathrm{ml}$ ethidium bromide. Gels were visualized using an Apligene UV CCD camera system.

\section{Real-time PCR}

Real-time PCR was conducted using SYBR Green PCR MasterMix according to the manufacturer's instructions. Quantitative real-time PCR (qRT-PCR) was performed using approximately $200 \mathrm{ng}$ of SYBR Green PCR MasterMix in an ABI 7300 system (Applied Biosystems, Foster City, CA, USA). PCR conditions were $95^{\circ} \mathrm{C}$ for $120 \mathrm{~s}, 60^{\circ} \mathrm{C}$ for $30 \mathrm{~s}$, and $72{ }^{\circ} \mathrm{C}$ for $30 \mathrm{~s}$ for 40 cycles. Sample cells from three plates were run in duplicate, using the threshold suggested by the software for the instrument to calculate $\mathrm{Ct}$. To normalize readings, we used $\mathrm{Ct}$ values from $18 \mathrm{~s}$ as internal controls for each run, obtaining a delta $\mathrm{Ct}$ value for each gene. (AIF F: GATTGCAA CAGGAGGTACTCCAAGA, R: GATTTGACTTCCCGTGAAATCTTCTC; Caspase 3 F: GGAAGCGAATCAATGGACTCTGG R: GCATCGACATCTGTACCAGACC; Caspase 8 F: AGAAGAGGGTCATCCTGGGAGA R: TCAGGACTTCCTTCAAGGCTGC; Caspase 9 F: TTCCCAGGTTाTGTTCCTG, R:CCTITCACCGAAACAGCATT; BAX F: TCAGGATGCGGTCCACCAAGAAG, R: TGTGTCCACGGCGGCAATCATC; BCL-2 F:GCCACTTACCTGAATGACCACC, R: AACCAGCGGTTGAAGCGTTCCT; and GAPDH F:GTCTCCTCTGACTTCAACAGCG R:ACCACCCTGTTGCTGT AGCCAA).

\section{Statistical analysis}

All data were reported as the mean ( \pm S.E.M.) of at least three separate experiments. A $t$-test or one-way ANOVA with post hoc test was employed for statistical analysis, with significant differences determined as $P<0.05$.

\section{ACKNOWLEDGEMENTS}

The authors appreciate the funding support provided by the National Science Council (Taiwan) (grant NSC 102-2314-B-006-050-MY3). 


\section{COMPETING INTERESTS}

The authors declare no conflict of interest.

\section{REFERENCES}

$1 \mathrm{Wu}$ HH, Liu YF, Yang SF, Lin WL, Chen SC, Han CP et al. Association of singlenucleotide polymorphisms of high-mobility group box 1 with susceptibility and clinicopathological characteristics of uterine cervical neoplasia in Taiwanese women. Tumour Biol 2016; 37: 15813-15823.

2 Gaffney D, Small B, Kitchener H, Young Ryu S, Viswanathan A, Trimble T et al. Cervix Cancer Research Network (CCRN): improving access to cervix cancer trials on a global scale. Int J Gynecol Cancer 2016; 26: 1690-1693.

3 Yang A, Farmer E, Wu TC, Hung CF. Perspectives for therapeutic HPV vaccine development. J Biomed Sci 2016; 23: 75.

4 Tomaić V. Functional roles of E6 and E7 oncoproteins in HPV-induced malignancies at diverse anatomical sites. Cancers 2016; 8: e95.

5 Wang HL, Lu X, Yang X, Xu N. Association of MBL2 exon1 polymorphisms with high-risk human papillomavirus infection and cervical cancers: a meta-analysis. Arch Gynecol Obstet 2016; 294: 1109-1116.

6 Cheng YT, Yang CC, Shyur LF. Phytomedicine-modulating oxidative stress and the tumor microenvironment for cancer therapy. Pharmacol Res 2016; 114: 128-143.

7 Amaral L, Spengler G, Molnar J. Identification of important compounds isolated from natural sources that have activity against multidrug-resistant cancer cell lines: effects on proliferation, apoptotic mechanism and the efflux pump responsible for multi-resistance phenotype. Anticancer Res 2016; 36: 5665-5672.

8 Hung CM, Chang CC, Lin CW, Chen CC, Hsu YC. GADD45y induces G2/M arrest in human pharynx and nasopharyngeal carcinoma cells by cucurbitacin E. Sci Rep 2014; 4: 6454.

9 Recio MC, Andujar I, Rios JL. Anti-inflammatory agents from plants: progress and potential. Curr Med Chem 2012; 19: 2088-2103.

10 Chen X, Bao J, Guo J, Ding Q, Lu J, Huang M et al. Biological activities and potential molecular targets of cucurbitacins: a focus on cancer. Anticancer Drugs 2012; 23: 777-787.

11 Dinan L, Harmatha J, Lafont R. Chromatographic procedures for the isolation of plant steroids. J Chromatogr A 2001; 935: 105-123.

12 Attard E, Martinoli MG. Cucurbitacin E, an experimental lead triterpenoid with anticancer, immunomodulatory and novel effects against degenerative diseases. A mini-review. Curr Top Med Chem 2015; 15: 1708-1713.
13 Jevtić B, Djedović N, Stanisavljević S, Despotović J, Miljković D, Timotijević G. Cucurbitacin E potently modulates the activity of encephalitogenic cells. J Agric Food Chem 2016; 64: 4900-4907.

14 Duncan KL, Duncan MD, Alley MC, Sausville EA. Cucurbitacin E-induced disruption of the actin and vimentin cytoskeleton in prostate carcinoma cells. Biochem Pharmacol 1996; 52: 1553-1560.

15 Hsu YC, Huang TY, Chen MJ. Therapeutic ROS targeting of GADD45Y in the induction of $\mathrm{G} 2 / \mathrm{M}$ arrest in primary human colorectal cancer cell lines by cucurbitacin E. Cell Death Dis 2014; 5: e1198.

16 Habib L, Jraij A, Khreich N, Fessi H, Charcosset C, Greige-Gerges H. Morphological and physicochemical characterization of liposomes loading cucurbitacin $E$, an anti-proliferative natural tetracyclic triterpene. Chem Phys Lipids 2014; 177: 64-70.

17 Hung CM, Chang CC, Lin CW, Ko SY, Hsu YC. Cucurbitacin E as inducer of cell death and apoptosis in human oral squamous cell carcinoma cell line SAS. Int J Mol Sci 2013; 14: 17147-17156.

18 Naoum GE, Tawadros F, Farooqi AA, Qureshi MZ, Tabassum S, Buchsbaum DJ et al. Role of nanotechnology and gene delivery systems in TRAIL-based therapies. Ecancermedicalscience 2016; 10: 660.

19 Mert U, Sanlioglu AD. Intracellular localization of DR5 and related regulatory pathways as a mechanism of resistance to TRAIL in cancer. Cell Mol Life Sci 2016.

20 Kiraz Y, Adan A, Kartal Yandim M, Baran Y. Major apoptotic mechanisms and genes involved in apoptosis. Tumour Biol 2016; 37: 8471-8486.

21 Gyurkovska V, Ivanovska N. Distinct roles of TNF-related apoptosis-inducing ligand (TRAIL) in viral and bacterial infections: from pathogenesis to pathogen clearance. Inflamm Res 2016; 65: 427-437.

22 Chen MJ, Tang WY, Hsu CW, Tsai YT, Wu JF, Lin CW et al. Apoptosis induction in primary human colorectal cancer cell lines and retarded tumor growth in SCID mice by sulforaphane. Evid Based Complement Alternat Med 2012; 2012: 415231.

(c) (i) This work is licensed under a Creative Commons Attribution 4.0 International License. The images or other third party material in this article are included in the article's Creative Commons license, unless indicated otherwise in the credit line; if the material is not included under the Creative Commons license, users will need to obtain permission from the license holder to reproduce the material. To view a copy of this license, visit http://creativecommons.org/licenses/ by/4.0/

(c) The Author(s) 2017 